Available online at GSC Online Press Directory

GSC Biological and Pharmaceutical Sciences

e-ISSN: 2581-3250, CODEN (USA): GBPSC2

Journal homepage: https://www.gsconlinepress.com/journals/gscbps

(RESEARCH ARTICLE)

\title{
Study on the nutritional and chemical composition of "Ogiri" condiment made from sandbox seed (Hura crepitans) as affected by fermentation time
}

\author{
Ahaotu Ndidiamaka Nnennaya ${ }^{1}$, Echeta Chinelo Kate $1,{ }^{*}$, Bede Njideka Evelyn ${ }^{1}$ Awuchi Chinaza Godswill 1,2 \\ Anosike Chinwe Linda ${ }^{1}$, Ibeabuchi Chidi Julian ${ }^{1}$ and Ojukwu Moses ${ }^{1}$ \\ ${ }_{1}^{1}$ Department of Food Science and Technology, Federal University of Technology Owerri, Owerri, Nigeria. \\ ${ }^{2}$ Department of Physical Sciences, Kampala International University, Kampala, Uganda.
}

Publication history: Received on 29 April 2020; revised on 09 May 2020; accepted on 11 May 2020

Article DOI: https://doi.org/10.30574/gscbps.2020.11.2.0115

\begin{abstract}
This study investigated the effects of fermentation time on the proximate composition, steroid, terpenoid, $\mathrm{pH}$, and titratable acidity of fermented condiment made from sandbox seed (Hura crepitans). Samples of dehulled sandbox seeds wrapped in blanched plantain leaves, cooked for 9 hours and fermented for 4 days were analyzed at different fermentation time. Unfermented sandbox seeds (SAA) had the highest level of proximate (moisture 41.9\%; carbohydrate 2.88\%; fibre 2.37\%; ash 1.8\%; protein 19.0\%; and lipid 32.05\%). Sample SAE (day4) showed the lowest values for all the proximate (moisture $48.35 \%$; carbohydrate $0.26 \%$; fibre $0.28 \%$; ash $2.5 \%$; protein $15.31 \%$; lipid $31.0 \%)$. SAE had the highest titratable acidity (TTA) content. Fermentation resulted to a significant decrease in total carbohydrate, protein and crude fibre, including a significant increase in moisture of the produced condiment. There is an insignificant decrease in total lipid, ash and $\mathrm{pH}$ as affected by the fermentation time. High availability of terpenoids was observed all through the fermentation period, while low steroid only appeared on the SAE (day 4) sample. The result of the research proved the potential use of sandbox (Hura crepitans) seeds in the production of Ogiri condiment.
\end{abstract}

Keywords: Sandbox seed; Ogiri condiment; Fermented condiment; Steroid; Terpenoid.

\section{Introduction}

Ogiri condiment is an important food additive associated with the Igbo people of the South East region of Nigeria. It is a product of fermentation of oils seeds such Castor oil seed (Ricinus communis), Melon seeds (Citrullus vulgaris, Colocynthis vulgaris) or other varieties, fluted Pumpkin seed (Telferia occidentalis), Soybeans(Glycine max) [1], [2], among other raw materials. Production of Ogiri involves the traditional method of uncontrolled solid substrate fermentation resulting in extensive hydrolysis of the protein and carbohydrate component [3]. The unpredicted variability in Ogiri condiment quality as a result of varying environmental factors [4]. Sandbox (Hura crepitans) also known as jabillo and possumwood, is an evergreen plant of the spurge family (Euphorbiaceae), native to tropical regions of North and South America, including the Amazon Rainforest; it is distinguished by the many dark, pointed spines and smooth brown bark [5]. These spines have caused it to be called Monkey no-climb. It is often and commonly planted in the cities and villages of some parts of Nigeria as a shade tree. It has been reported that the seeds of sandbox contains oil which may be useful in industries for even food and feed production [6], [7], [8], respectively. The oil rich seeds of Sandbox (Hura crepitans) have indeed not found its way into the annals of proper food use. The process of achieving its usefulness might be done through fermentation into a condiment, which is a known method of food preservation known to man [9]. The processing of foods by fermentation has excellent advantages such as the

\footnotetext{
* Corresponding author: Echeta Chinelo Kate, +2348135166963, Email: nellykay91@gmail.com
} 
elimination of undesirable flavours and odours, production of a good flavour, increased digestibility, synthesis of desirable constituents and changes in physical state, longer shelf-life and destruction of inhibitors [10].

Ogiri condiment production from castor oil seed (Ricinus communis), typically involves the following steps (1) dehulling of the seeds (2) Washing and wrapping of the de-hulled seeds in plantain leaves (3) Boiling of the wrapped de-hulled seeds for 9 - 18 hours. (4) cooling and fermentation of the wrapped, boiled de-hulled seeds at a steady temperature $\left(35^{\circ} \mathrm{C}\right)$ and humidity for $3-4$ days (5) unwrapping and milling into a paste using a mortar and pestle (6) packaging on a fresh blanched leaves (7) ageing under the sun for 2-3 days before consumption. The anti-nutritional factors in the oilseeds are reduced through fermentation, while flavour compounds, digestibility and nutritive value are improved and developed [11], [3]. Bacteria of the genus Bacillus were responsible for the fermentation of Ogiri condiment [12], [9], [13]). In recent years, plant proteins have been playing significant roles in combating food insecurity in developing countries where average protein intake is less than required [14]. Due to inadequate supplies of food proteins, there has been a constant search for unconventional legumes or oilseeds as new protein sources for use as both functional supplements [15]. Modern researches have thus focused more on oilseed crops as largely unexploited sources of food crops. Sandbox (Hura crepitans) seed falls into this group of underutilized plants seeds. Sandbox, as an underutilized plant in Nigeria, is often grown as an ornamental shade plant in the tropics [16], [17]. Given the high level of protein and oil in sandbox seed, processing the whole seed through fermentation into a condiment will reduce the overdependence of condiment production on Castor seed and Melon seed and enhance its utilization as food ingredients.

This study determined the effect of fermentation timeon the nutritional composition, steroid, terpenoid, $\mathrm{pH}$ and the total titratable acidity of Ogiri condiment from sandbox (Hura crepitan) seed.

\section{Materials and methods}

\subsection{Source of raw material}

The mature, dry Sandbox (Hura crepitan) seeds used in the study were obtained from Port Harcourt, Rivers State, Nigeria. The hard pumpkin-shaped capsules were broken to release the light brown flat seed contained in the hollow chamber. The seeds were mechanically de-shelled using a knife. All equipment/instrument used for the study were obtained from the Plant Physiology and Biotechnology Research Laboratory of the University of Port-Harcourt, Nigeria. All chemical/Reagents in this work were of analytical grade.

\subsection{Sample preparation and fermentation}

The sorted cream colored cotyledon (2500 gm) divided into five (5) different samples (SAA, SAB, SAC, SAD, SAE) weighing $500 \mathrm{gm}$ each. Each of the samples was processed into Ogiri condiment using the method described below. The sorted and washed samples were wrapped in blanched plantain leaves and boiled for 9 hours in 3 liters of water until the water dried up. After boiling, the samples (SAA, SAB, SAC, SAD and SAE) were placed in an incubator at $35^{\circ \mathrm{C}}$ for four days to undergo fermentation. Samples were analyzed at different fermentation days for the chemical and proximate composition in duplicate.

\subsection{Determination of the proximate composition of the fermented sandbox seed}

The moisture, fat, protein, carbohydrate, crude fibre, ash composition of the fermented samples was determined using the method described in AOAC [18].

\subsection{Determination of moisture content}

The method as defined by AOAC, [18] was used; One (1) gram of the mashed, fermented sandbox seed sample was weighed into a clean dried porcelain evaporating dish. This was placed in an oven to maintain a temperature of $105^{\circ} \mathrm{C}$ for 6 hours. The evaporating dish was cooled in desiccator to room temperature, then it was re-weighed and recorded.

The moisture content was calculated as follow;

$$
\% \text { moisture content }=\frac{\text { change in weight }}{\text { Initial weight of the sample before drying }} \times 100
$$




\subsection{Determination of ash content}

One (1) gram of the mashed sandbox seed sample was weighed into porcelain crucible, which was previously pre-heated and weighed. The crucible was inserted into a muffle furnace and regulated to a temperature of $630^{\circ} \mathrm{C}$ for three hours and allowed to cool to room temperature and re-weighed.

The ash content was calculated as follow;

$$
\frac{\mathrm{W} 2-\mathrm{W} 1}{\mathrm{~W}} \times 100
$$

Where, $\mathrm{W}=$ Dry weight of food sample, $\mathrm{W} 1=$ weight of crucible, $\mathrm{W} 2$ = weight of crucible and ash

\subsection{Determination of carbohydrate content of fermented sandbox seed sample (by Cleg Anthrone method)}

The mashed sandbox seed Sample of $(0.1 \mathrm{gm})$ was weighed into $25 \mathrm{~mL}$ volumetric flask containing 1 (mL) distilled water and $1.3 \mathrm{~mL}$ of $62 \%$ perchloric acid. It was shaken for a period of 20 mins to homogenize completely. The flask was made up to $25 \mathrm{~mL}$ mark with distilled water and stopper. The solution formed was filtered through a glass filter paper, allowed to sediment and decanted. Filtrate $(1 \mathrm{~mL})$ was collected and transferred into a $10 \mathrm{~mL}$ test-tube. This was diluted to volume with distilled water, $1 \mathrm{~mL}$ of working solution was drawn using pipette into a clean test tube, and 5 $\mathrm{mL}$ of Anthrone reagent was mixed similarly. The whole mixture was read at $630 \mathrm{~nm}$ wavelength using the $1 \mathrm{~mL}$ distilled water and the $6 \mathrm{~mL}$ Anthrone reagent prepared was blank. Glucose solution of $0.1 \mathrm{~mL}$ was also prepared and was treated as the sample with Anthrone reagent.

The absorbance of the standard glucose was calculated using the formula;

$\%$ carbohydrate (as glucose) $=\frac{25 \mathrm{x} \text { absorbance of sample }}{\text { Absorbance of standard glucose }}$

\subsection{Determination of lipid content by Soxhlet extraction}

Two (2) grams of sample was inserted into a filter paper and was placed into a Soxhlet extractor. The extractor was put into a pre-weighed dried distillation flask. Then the solvent (acetone) was introduced into the distillation flask via condenser end attached to the Soxhlet extractor. The setup was held in place with a retort stand clamp. The cooled water jet was allowed to flow into the condenser, and the heated solvent was refluxed as a result. The lipid in the solvent chamber was extracted in the process of continuous refluxing. When the lipid was observably extracted entirely from the sample under rest, the condenser and the extractor were disconnected, and the solvent evaporated to concentrate the lipid. The flask was then dried in the air oven to constant weight and re-weighed to obtain the weight lipid.

The lipid content was calculated as follow;

$$
\frac{\text { Weight of the extracted }}{\text { Weight of sample }} \times 100
$$

\subsection{Determination of protein content (By Kjeldahl Method)}

\subsubsection{Stage 1: Digestion}

About 0.1 gm of the mashed sandbox sample was weighed into a clean conical flask of $250 \mathrm{~mL}$ capacity, 3 gm of Digestion catalyst was added into the flask and $20 \mathrm{~mL}$ concentrated sulphuric acid was also added, and the sample was heated to digest. The content from black to sky-blue colouration, the digest was cooled to room temperature and was diluted to $100 \mathrm{~mL}$ with the distilled water.

\subsubsection{Stage 2: Distillation}

Twenty $(20 \mathrm{~mL})$ diluted digest was measured into a distillation flask, and the flask was held in place on the electrothermal heater or hotplate. The distillation flask was attached a Liebig condenser connected to a receiver containing 10 
$\mathrm{mL}$ of $2 \%$ boric acid indicator. About $40 \mathrm{~mL}$ Sodium hydroxide was injected into the digest via a syringe attached to the mono armsteel head until the digest becomes strongly alkaline. The mixture was heated to boiling and the distilled ammonia gas via the condenser into the receiver beaker. The colour of the boric acid change from purple to greenish as ammonia distillate was Introduced into the boric acid.

\subsubsection{Stage 3: Titration}

The Distillation was titrated with standard 0.1 Nhydro chloric acid solution, the volume of hydro chloric acid added to affect the change which was recorded as titer value

The protein content was calculated as follow;

$$
\% \text { crude protein }=\% \mathrm{~N} 2 \frac{100 \times \mathrm{N} 14 \times \mathrm{VfT}}{\mathrm{W} \times 1000 \times \mathrm{Va}} \times 6.25
$$

Where $\mathrm{W}=$ weight of sample analyzed, $\mathrm{N}=$ Concentration of $\mathrm{H}_{2} \mathrm{SO}_{4}$ titrant, $\mathrm{V}_{\mathrm{f}}=$ Total volume of digest, $\mathrm{V}_{\mathrm{a}}=\mathrm{Volume}$ of digest distilled, $\mathrm{T}$ = titer value- blank

\subsection{Determination of crude fibre content}

The crude fibre content was done using the Wende [19]. A measured weight of each sample (5.0 g) was defatted (as in fat analysis). The defatted sample was boiled under reflux for 30 minutes in $150 \mathrm{~mL}$ of $1.25 \% \mathrm{H}_{2} \mathrm{SO}_{4}$ solution, and care was taken to avoid loss of particles during the whole process.

After boiling for 30 minutes in acid solution, the samples were washed with repeated portions of hot distilled water until the wash water was free of acid (through litmus test). Meanwhile, during the washing, a two-fold muslin cloth was used to retain the particles of the sample, which was carefully transferred back to the flask and boiled again.

This time, in $150 \mathrm{~mL}$ of $1.25 \% \mathrm{NaOH}$ solution, it was washed as before and then transferred quantitatively into a weighed crucible in which it was dried in the oven at $105^{\circ} \mathrm{C}$ for an hour; it was then cooled in a desiccator and re-weighed.

The crucible fibre was calculated as follows;

$$
\% \text { fiber }=\frac{\mathrm{W} 2-\mathrm{W} 3}{\mathrm{~W} 1} \times 100
$$

$\mathrm{W} 1$ = weight of sample analyzed

W2 = sample after boiling + weight of crucible drying

W3= Weight of crucible + sample after ashing.

\subsection{Determinations of other chemical components.}

The chemical analysis that was carried out was steroid, terpenoid, pH and titratable acidity, which was determined using the method described in AOAC, [18].

\subsubsection{Determination of steroids}

Two (2) $\mathrm{mL}$ of acetic anhydride was added to 0.5 gm ethanol extract of each sandbox sample with $2 \mathrm{~mL} \mathrm{H}_{2} \mathrm{SO}_{4}$, a colour change from violet to blue or green indicated the presence of steroids.

\subsubsection{Determination of Terpenoids}

Five (5) $\mathrm{mL}$ of each extract was mixed in $2 \mathrm{~mL}$ chloroform and concentrated $\mathrm{H}_{2} \mathrm{SO}_{4}$ (3 mL) was carefully added to form a layer. A reddish-brown colouration of the interface form to suggest positive result for the presence of Terpenoids. 


\subsection{3. $p H$ determination}

The $\mathrm{pH}$ of the fermenting mashes was determined using the methods described in AOAC, [18]. Ten grams (10 gm) of the samples were put into $200 \mathrm{~mL}$ beaker and $100 \mathrm{~mL}$ of distilled water added to it. The $\mathrm{pH}$ was then measured using a standardized $\mathrm{pH}$ meter (Prazis ions $\mathrm{pH}$ meter ES10 model).

\subsubsection{Total Titratable Acidity (TTA)}

Ten grams (10 gm) of the sample was homogenized in $200 \mathrm{~mL}$ of distilled water and filtered using Whitman filter paper. $10 \mathrm{~mL}$ of filtrate was transferred into a $250 \mathrm{~mL}$ conical flask. Two (2) drops of phenolphthalein was added and titrated against $25 \mathrm{~mL}$ of $0.1 \mathrm{~mL} \mathrm{NaOH}$ solution until the mixture turned pink. The titer volume was recorded, and the percentage titratable acidity (TTA\%) as lactic acid was calculated by multiplying the titer volume by 0.09 [19].

The data obtained from the study were analysed using Analysis of Variance (ANOVA) and the means separated using Fisher's Least Significant Difference (LSD). The data were processed using Microsoft Excel (2007).

\section{Results and discussion}

Table 1 Mean of duplicate determinations of the nutritional composition of Sandbox Ogiri condiment as affected by fermentation time

\begin{tabular}{|c|c|c|c|c|c|c|}
\hline Parameter & SAA (Day 0) & SAB ( Day 1) & SAC (Day 2) & SAD (day 3) & SAE (day 4) & LSD \\
\hline Moisture (g/100g) & $41.9 \pm 0.10^{\mathrm{e}}$ & $42.86 \pm 0.10^{\mathrm{d}}$ & $44.65 \pm 0.20^{c}$ & $46.50 \pm 0.1^{\mathrm{b}}$ & $48.35 \pm 0.10^{\mathrm{a}}$ & 0.460 \\
\hline Carbohydrate $(\mathrm{g} / 100 \mathrm{~g})$ & $2.88 \pm 0.08^{a}$ & $2.77 \pm 0.07^{\mathrm{a}}$ & $2.38 \pm 0.08^{b}$ & $2.17 \pm 0.07^{\mathrm{b}}$ & $1.26 \pm 0.06^{C}$ & 0.260 \\
\hline Fiber $(\mathrm{g} / 100 \mathrm{~g})$ & $2.37 \pm 0.01^{\mathrm{a}}$ & $2.15 \pm 0.07^{\mathrm{b}}$ & $1.82 \pm 0.10^{\mathrm{c}}$ & $1.60 \pm 0.1^{\mathrm{dc}}$ & $1.58 \pm 0.08^{\mathrm{ec}}$ & 0.289 \\
\hline Ash $(\mathrm{g} / 100 \mathrm{~g})$ & $1.80 \pm 0.10$ & $1.90 \pm 0.20$ & $2.00 \pm 0.10$ & $2.00 \pm 0.10$ & $2.50 \pm 0.10$ & NSD \\
\hline Protein $(g / 100 g)$ & $19.0 \pm 0.08^{\mathrm{a}}$ & $18.47 \pm 0.07^{\mathrm{b}}$ & $17.5 \pm 0.05^{c}$ & $16.53 \pm 0.03^{d}$ & $15.31 \pm 0.30^{\mathrm{e}}$ & 0.520 \\
\hline Lipid/Fat (g/100g) & $32.05 \pm 0.05$ & $31.85 \pm 0.05$ & $31.65 \pm 0.05$ & $31.20 \pm 0.10$ & $31.00 \pm 0.5$ & NSD \\
\hline
\end{tabular}

$(p>0.05)$. SAA= 0-day fermentation; SAB=1-day fermentation; SAC= 2-day fermentation; SAD= 3-day fermentation; SAE= 4-day fermentation; LSD= Least significant difference; NSD= No significant difference; superscripts (a,b,c,d,e) = shows order of Significant Difference.

From the result of the proximate analysis of sandbox seed sample shown in Table 1, it was observed that the moisture content of the sandbox condiment increased as the period of fermentation increased from SAA (day 0) to SAE (day 4) at the range of $41.9 \pm 0.1$ to $48.53 \pm 0.1$. These values were too high compared to the values of $12.82 \pm 0.01$ [17], for the "Chemical Examination of Sandbox (Hura crepitans) Seed: Proximate, Elemental and Fatty Acid Profile." Also, the values obtained in this study were higher than the values of 5.123 to $8.23 \%$ [20], for "Proximate composition and functional properties of sandbox seeds as influenced by processing methods". The increase in the moisture content after boiling the seeds and fermenting for one day could be attributed to the moisture absorbed by the seed during the boiling process [21]. There was a significant difference in the moisture content of the fermented sandbox seed.

Moreover, the subsequent increase in moisture content as fermentation progressed could be attributed to the hydrolytic decomposition of the product during fermentation. Hence in other to solve the problem, they can be fermented for a shorter period to prevent the accumulation of moisture which would reduce the storage shelf-life of the fermented condiment [22].

During processing, foods usually undergo different modifications or rearrangements in which specific chemical and biochemical changes may take place depending on the presence of moisture [23], [24]. Therefore, the comprehension of moisture content is vital to predicting the behaviour of foods during processing, storage, and consumption.

There was a significant decrease of $2.88 \pm 0.08$ to $1.26 \pm 0.06 \%$ in the carbohydrate content of the sandbox condiment as the fermentation took place from day zero $(0)$ to the fourth day. These values were slightly related to the percentage carbohydrate values of 2.15 to $31.55 \%$ of sandbox seeds as influenced by processing methods [20]. Due to enzymatic 
activities, the observed changes in carbohydrate with fermentation agreed with the report of [25], [15], on fermented fluted pumpkin seed and fermented millet, respectively. The apparent decrease may be attributed to increased activity of amylolytic enzymes which hydrolyses starch and a n other complex carbohydrate to more straight forward sugar. The simple sugars provide energy for the fermenting microorganism as a carbon source for the possible synthesis of other compounds.

Fermentation also resulted to a significant decrease in the crude fibre of the fermented sandbox Ogiri condiment in this study, from $2.37 \pm 0.01$ to $1.58 \pm 0.08 \%$ which could be attributed to the degradation of the fibre by fermentative organisms [26]. [20], reported values of 0.02 to $3.05 \%$ for crude fibre but were lower than the values of $7.65 \pm 0.03 \%$ reported by [17]. These values were related to the values obtained in this study. The fibre in food generally offers a variety of health benefit, and it is essential in reducing the risk of chronic diseases.

Total ash was observed to increase with fermentation time from $1.8 \pm 0.1$ to $2.5 \pm 0.1 \%$. High ash content implies high mineral content which helps retard the growth of particular microorganism, and some mineral is necessary for diets for health benefits [27]. The ash content of food gives an idea of the total quantity of the mineral elements in the menu [23]. It indicates the inorganic elemental composition after organic materials (including fats, carbohydrates, and proteins) and moisture are removed by oxidation or incineration [24].

The protein content of the fermenting samples significantly reduced from $19.00 \pm 0.08 \%$ on the SAA sample to 15.31 $\pm 0.08 \%$ on the SAE sample. This result showed that there were protein loss and breakdown as a result of fermentation. Bainbridge, [20] reported protein contents of sandbox flour samples of 31.08 to $87.49 \%$., which were slightly higher than the values reported in this study. The decrease may be associated with nutrient loss during leaching, and also might be related to the microorganism responsible for fermenting the seed must have used part of the protein of the seed for their metabolic activities.

The crude fat content of the samples showed an insignificant decrease from $32.05 \pm 0.05 \%$ to $31.0 \pm 0.5 \%$ through the fermentation period. These values were within the range of crude fat values reported by [20]. The high lipid content of this product is of some nutritional significance considering the high caloric value of lipid.

Table 2 Titratable acidity and pH of Sandbox (Hura crepitans) condiment.

\begin{tabular}{lllllll}
\hline Parameter & SAA & SAB & SAC & SAD & SAE & LSD \\
\hline Titratable acidity (\%) & $0.2 \pm 0.00$ & $0.2 \pm 0.01$ & $0.2 \pm 0.02$ & $0.2 \pm 0.03$ & $0.25 \pm 0.05$ & NSD \\
Ph & $5.7 \pm 0.10$ & $5.7 \pm 0.20$ & $5.7 \pm 0.00$ & $5.6 \pm 0.20$ & $5.4 \pm 0.20$ & NSD \\
\hline $\begin{array}{l}\text { (p>0.05). SAA- 0day fermentation; SAB-1day fermentation; SAC- 2day fermentation; SAD-3day fermentation; SAE- 4day fermentation; } \\
\text { LSD- least significant difference; NSD- no significant difference }\end{array}$
\end{tabular}

The results of the titratable acidity and $\mathrm{pH}$ are shown in Table 2. The titratable acidity (TTA) showed an insignificant increase from $0.2 \pm 0.00$ to $0.25 \pm 0.05 \%$ on the last day of fermentation. Titratable Acidity (TTA), is the approximation of total acidity of a solution and is used as a quality parameter in food industries. The $\mathrm{pH}$ values of the fermenting samples remained constant at pH 5.7 from day 0 (SAA) through day 3 (SAD) and finally decreased insignificantly to Ph 5.4 on the last day of fermentation. Increase in TTA was accompanied by a decrease in $\mathrm{pH}$, as shown in Table 2.

Table 3 Availability and intensity of steroid and terpenoid in Sandbox (Hura crepitans) condiment.

\begin{tabular}{|c|c|c|}
\hline Sample & Steroid (Availability and Intensity) & Terpenoid (Availability and Intensity) \\
\hline SAA & N.D & +++ \\
\hline SAB & N.D & +++ \\
\hline SAC & N.D & +++ \\
\hline SAD & N.D & +++ \\
\hline SAE & + & +++ \\
\hline
\end{tabular}


The result on table 3, shows a high presence of terpenoid, which fermentation never affected, this confirmed the report by [28] on the detection of terpenoid at moderate levels in sandbox tree (Hura crepitans) seed oil. Terpenoid represents the largest and most diverse class of chemicals among the myriad compounds produced by the plant, the importance of this chemical has gained increasing attention to develop strategies for sustainable pest control and abiotic stress protection and also could bring about flavonoids. Terpenes and terpenoids of several kinds are found in various medicinal plants, where they serve to repel herbivores and are strongly aromatic, their scent makes them useful and suitable in essential oils [29].

Steroids were absent in the samples but were mildly present in day four, which might be due to longer fermentation time. As a result, the availability of these metabolites in moderate-intensity shows that the adequate consumption of this condiment will help hormonal boosting in the vertebrates.

\section{Conclusion}

The study revealed that sandbox seed (Hura crepitan) might have good potential for use in fermented condiment production, thereby finding its way into the annals of condiment substrate. This is demonstrated in the proximate analysis which revealed that the product contained a considerable quantity of useful nutritional substances (crude protein, fat, ash and carbohydrate) with crude fibre which is desirable indigestibility, decrease in blood cholesterol and reduce the risk of large bowel cancer. The high content of oil and high presence of terpenoids in the sandbox seed Ogiri shows that the fermented condiment might have high nutraceutical potential if further investigation is carried out. Longer fermentation can bring about the presence of steroid which is responsible for many osmoregulatory functions of thephysiological factor of human. The seed could therefore, be used as one of the underutilized food source to solve the problem of malnutrition in third world countries.

\section{Compliance with ethical standards}

\section{Acknowledgments}

The authors acknowledge some of the staffs of Department of Food Science and Technology, Federal University of Technology Owerri, Nigeria, and the laboratory technician of the Plant Physiology and Biotechnology Research Laboratory of the University of Port-Harcourt, Nigeria, as well as the Department of Physical Sciences, Kampala International University, Kampala, Uganda, who in one way or the other contributed to the success of this research.

\section{Disclosure of conflict of interest}

We have no conflicts of interest to disclose

\section{References}

[1] Ojinnaka MC and Ojimelukwe PC. (2012). Effect of fermentation period on the organic acid and amino acid contents of Ogiri from Ricunus communis. Journal of Food Technology, 10, 140-150.

[2] Dimejesi SA and Odibo FJC. (2017). Determination of heavy metals, Aflatoxin and Amino Acid Profile of fermented seeds of Telfairia occidentalis. Proceedings of the 41st Nigeria Insitute of Food Science and Technology (NIFST) Conference and Annual Genral Meeting at Abuja, 251-252.

[3] Achi OK. (2005). Traditional fermented protein condiments in Nigeria: Review. African Journal of Biotechnology, 4(13), 1612-1621.

[4] Ogueke CC, Okoli AI, Owuamanam CI and Nwosu JN. (2013). Fermentation of melon seeds for "Ogiriegusi" as affected by fermentation variables using Bacillus subtilis. Malaysian Journal of Microbiology, 9(4), 79 - 288.

[5] Burkill HM. (1994). The useful plants of west tropical Africa, 2, 84-85.

[6] Olatidoye OP, Adeleke AE, Adegbite SA and Sobowale SS. (2010). Chemical composition and nutritional evaluation of sandbox (Hura crepitans) seed flour for domestic consumption and industrial utilization in Nigeria. Journal of Medical Applied Biosciences, 2, 72-83.

[7] Okolie PN, Uaboi-Egbenni PO and Ajekwene AE. (2012). Extraction and quality evaluation of sandbox tree seed (Hura crepitans) oil. World journal of agricultural science, 8(4), 359-365. 
[8] Mohammed B, Gabel M and Karlsson LM. (2013). Nutritive values of the drought tolerant food and fodder crop enset. Afr. J. Agric. Sci., 8(20), 2326-2333.

[9] Omafuvbe BO, Shonukan $O 0$ and Abiose SH. (2000). Microbiological and biochemical changes in the traditional fermentation of soybean for soy dawa-dawa Nigerian food condiment. Food Microbiology, 17, 469- 474.

[10] Odunfa SA. (1981). Microorganisms associated with fermentation of African locust bean (Parkia filicoidea) during "iru" preparation, J. Plant Foods, 3(4), 245-250.

[11] Mensah PPA, Tomkins AM, Draser BS and Harrison TJ. (1990). Fermentation of cereals for reduction of bacterial contamination of weaning foods in Ghana. The Lancet, 336, 140-143.

[12] Ojinnaka MC, Ojimelukwe PC and Ezeama CF. (2013). Microbial and enzymatic changes associated with the production of ogiri from castor oil bean using Bacillus subtilis as starter culture. Sky Journal of Food Science, 2(2), 10-18.

[13] Omafuvbe BO, Olumuyiwa SF, Bolanke AO and Steve RS. (2004). Chemical changes in Africa locust beans (Parkia biglobosa) and melon (Citrullus vulgaris) seeds during fermentation to condiment. Pakistan journal of nutrition, 3(3), 140-145.

[14] Khalid EK, Babiker EE and El Tinay A.H. (2003). Solubility and functional properties of fermented sesame seed protein as influenced by pH and salt concentrate. Food chemistry, 82(3), 361-366.

[15] Onweluzo JC and Nwabugwu CC. (2009). Fermentation of Millet (Pennisetum americanum) and Pigeon Pea (Cajanus cajan) Seeds for Flour Production: Effects on Composition and Selected Functional Properties. Pakistan Journal of Nutrition, 8, 737-744.

[16] Swaine MD and Beer T. (1977). Explosive seed dispersal in Hura crepitan L. (Euphorbiaceae). New Phytologist, 78(3), 695-708.

[17] Oyeleke GO, Olayiwola OA and Latona DF. (2012). Chemical Examination of Sandbox (HuraCrepitans) Seed: Proximate, Elemental and Fatty Acid Profile. IOSR Journal of Applied Chemistry, 1(2), 10-1.

[18] AOAC. (1990). Association of Official Analytical Chemists. 15thEdition, AOAC. Inc. Arlington, V.A.U.S.A, 19451962.

[19] James SC. (1996). Experimental Methods. In: Analytical Chemistry of Foods, Champman \& Hall, New York, 28.

[20] Bainbridge Tk and Westby k. (1996). Method of assessing quality characteristics of non-grained starch Staples. Natural resource institute chattamU, 3.

[21] Ige MM, Gbadamosi SO and Solana OI. (2019). Proximate composition and functional properties of sandbox seeds as influenced by processing methods. Ife Journal of Science, 21(1), $129-144$.

[22] Auta J and Anwa EP. (2007). Preliminary studies on Albizia lebbeck seeds: proximate analysis and phytochemical screening. Research Journal of Biological Sciences, 2, 33-35.

[23] Idowu DO and Abegunrin PT. (2014). A study of some hydro-thermal properties of sandbox (Hura crepitans) seed. Agricultural engineering international:CIGR journal, 16(4), 225-260.

[24] Hannington T, Awuchi CG and Mihigo R. (2020). Comparative Study of the Proximate Composition and Functional Properties of Composite Flours of Amaranth, Rice, Millet, and Soybean. American Journal of Food Science and Nutrition, 6(1), 6-19.

[25] Awuchi CG. (2019b). Proximate Composition and Functional Properties of Different Grain Flour Composites for Industrial Applications. International Journal of Food Sciences, 2(1), 43 - 64.

[26] Achinewhu SC and MO Isichei. (1990).The nutritional evaluation of fermented fluted pumpkin seeds (Telferia occidentalis Hook). Discovery and Innovation, 2, 62-65.

[27] Babalola AO and Giwa OE. (2012). Effect of fermentation on nutritional and anti-nutritional properties of fermenting Soy beans and the antagonistic effect of the fermenting organism on selected pathogens. International Research Journal of Microbiology (IRJM) (ISSN: 2141-5463) 3(10), 333-338.

[28] Osborn HT and Akoh CC. (2003). Effects of natural antioxidants on iron-catalyzed lipid oxidation of structured lipid-based emulsions. J Amer Oil Chem.'Soc 80, 847-852.

[29] Ajani 00, Owoeye FT, Owolabi FE, Akinlabu DK and Audu OY. (2019). Phytochemical screening and nutraceutical potential of sandbox tree (Hura crepitans L.) seed oil. Foods and Raw Materials, 7(1), 143-150. 
[30] Awuchi CG. (2019a). Medicinal Plants: the Medical, Food, and Nutritional Biochemistry and Uses. International Journal of Advanced Academic Research, 5 (11), 220 - 241.

\section{How to cite this article}

Ahaotu NN, Echeta CK, Bede NE, Awuchi CG, Anosike CL, Ibeabuchi CJ and Ojukwu M. (2020). Study on the nutritional and chemical composition of "Ogiri" condiment made from sandbox seed (Hura crepitans) as affected by fermentation time. GSC Biological and Pharmaceutical Sciences, 11(2), 105-113. 